J Progress Hum Serv. 2017 ; 28(3): 134-139. doi:10.1080/10428232.2017.1343640.

\title{
The Opposition
}

\author{
Alexis Jemal \\ Social Work, Rutgers University Graduate School of New Brunswick, New Brunswick, New \\ Jersey, USA
}

\section{Abstract}

Although social workers have an ethical and professional mandate to address inequity, theoretical and treatment approaches usually fail to address historical and structural contexts. In opposition, radical social work bridges individual and community practice by acknowledging that macro forces have micro consequences; micro practices are reflective of macro socio-political processes; and, by opposing the socio-structural forces underlying individual problems. By adopting transformative, anti-oppressive frameworks and practices, radical social workers make visible the invisible social-ecological factors that hurt people, including institutionalized white privilege; transform systems to help individuals rather than helping individuals cope with oppressive systems by reinforcing marginalized roles in accordance with inferior treatment; and develop transformative potential in self and others.

\section{Keywords}

Critical consciousness; oppression; privilege; transformative potential

Through the vehicle of opposition, we develop awareness. We know sweet because we know sour. Perhaps we can know radical social work in contrast to traditional social work. One critique is that traditional social work unwittingly acts as a tool of social control in the enforcement of the status quo, perpetuating social injustice (i.e., oppression and privilege) (Mullaly, 2002; Sakamoto \& Pitner, 2005; Windsor, Jemal, \& Benoit, 2014). Even though the field of social work aligns itself with the person-in-environment perspective-a holistic framework stemming from the ecological systems model that perceives the personal and structural challenges that underlie a client's presenting problem (Bronfenbrenner, 1977; Dybicz, 2015) - theoretical and treatment approaches usually focus on individual behavior and fail to address historical and structural contexts (Windsor, Jemal, \& Alessi, 2015). According to Mullaly (2002), conventional social work addresses the suffering or symptoms caused by social injustice, such as homelessness, depression, and unemployment, while ignoring the oppression at their core. Traditional social work may assist oppressed individuals in maintaining their inferior status by facilitating conformity with oppressive societal norms and practices (Mullaly, 2002); in contrast, radical social work engenders a response to create innovative structural solutions to social problems that empower oppressed 
groups to challenge oppressive realities (Mullaly, 2002; Windsor, Pinto, Benoit, Jessell, \& Jemal, 2014).

Social injustice flourishes in societies that have limited capacity for analysis and action (Freire, 1970). Thus, transformative potential, which has two components-transformative consciousness and transformative action (Jemal, 2016) — provides a framework for radical social work practice, such as clinical counseling, community organizing, policy advocacy, education, and research (Mullaly, 2002). Transformative potential refers to the levels of consciousness and action by which individuals analyze their current situations, develop a deeper understanding of causes and effects, and devise, implement, and evaluate solutions to their problems (Jemal, 2016). These ideas are grounded in critical consciousness theory, which focuses on the role of oppression and privilege in creating and sustaining social (e.g., unemployment, disease, crime) and individual (e.g., substance use, HIV/STI-risk behavior) dysfunction (Freire, 1970; Mullaly, 2002; Windsor, Jemal, et al., 2014). Critical consciousness has been identified as the antidote to social injustice (Watts, Griffith, \& Abdul, 1999).

From a critical-consciousness perspective, individual and social dysfunction is a direct consequence of structural and internalized oppression (Chronister \& McWhirter, 2006; Mullaly, 2002). The cyclical nature of processes and outcomes of social injustice create a self-perpetuating phenomenon; like a virus, social injustice infects the host system. Then the infected system malfunctions and produces oppressive outcomes instead of its usual product. The criminal justice system may provide a practical example, in that this system functions to apprehend, prosecute, sentence, and punish those who commit criminal offenses; however, this system has mass-produced gross injustices against the poor and people of color (Alexander, 2010). Many of our societal systems are no longer able to function and carry out their intended purposes. As a result, members of certain groups are systematically oppressed.

Transformative consciousness is an awareness of institutional, historical, and systemic forces that limit and promote opportunities for particular groups (Freire, 1970; Ginwright \& James, 2002; Hatcher et al., 2010; Jemal, 2016). For example, transformative consciousness can provide a lens for understanding how individuals are affected by internalized and structural oppression and to explore a family's intergenerational beliefs that support oppressive thinking and behaviors. "As people become increasingly critical, they move from a position of passivity, pessimism, victimization, and acceptance of the status quo to a role of collaboration in actively creating situations that are more just, liberating, and loving" (Alschuler, 1986, p. 493). Transformative action includes anti-oppressive individual and collective action to overcome and dismantle structural and internalized oppression, such as engaging in community-based participatory research with marginalized populations or promoting community organizing and social activism (Smith \& Jemal, 2015; Windsor, 2013).

In opposition to traditional social work, radical social work should connect individuals with community change (Carlson, Engebretson, \& Chamberlain, 2006; Corning \& Myers, 2002). For instance, when addressing substance use frequency in oppressed populations, "it is 
crucial to understand substance use as a complex phenomenon interrelated with poverty, violence, and low social capital (Windsor, Pinto, et al., 2014, p. 403; see also Dunlap \& Johnson, 1992). Treatment of oppressed individuals and families in isolation from their socio-political contexts ignores the influence of oppressive forces on the daily experiences of these individuals (Dunlap \& Johnson, 1992; Windsor, Benoit, \& Dunlap, 2010). The socioecological model (Bronfenbrenner, 1977) posits that programs will be most successful if changes are promoted at multiple levels, from person-oriented interventions to public policy (Stokols, 1992). The development of transformative potential may help social workers form collaborative partnerships for anti-oppressive work in their communities. This work could include: 1) reducing situations for continued oppression and privilege; 2) forming therapeutic alliances that are grounded in the clients' realities and that validate the clients' experiences; 3) helping clients navigate systemic oppression within multiple systems of care, while simultaneously acting to change those systems; 4) recognizing and challenging personal biases and the biases of others; and 5) taking collaborative action with communities to address structural injustice (Garcia, Kosutic, McDowell, \& Anderson, 2009; Hernandez, Almeida, \& Dilan Del-Vecchio, 2005; Mullaly, 2002; Sakamoto \& Pitner, 2005).

Three of the most powerful tools used to perpetuate social injustice that radical social work could address are silence, division, and ignorance. The lack of critical discussion about social injustices provides the supportive environment for oppression to spread rampantly from the individual to macro systems. Transforming conversations could be a major outcome of radical social work to break the silence. Group participation in discussions that reinforce critical reflection on issues of systemic causal factors allow the "exchange of ideas or opinions between citizens within a community that centers on an awakening of potentially conflicting views of beliefs or values about social justice issues (such as racism, sexism, ableism, heterosexism/homophobia)" (Watt, 2007, p. 116). Thus, transforming conversations has two meanings: 1) changing the conversation to focus on the underlying issues of systemic social injustice; and 2) using these conversations to expose social injustice for the opportunity to find solutions.

The goal of Freire's (1970) work was to foster liberation, not by liberating the oppressed, but by working alongside the oppressed while they liberated themselves (Freire, 1970; Smith-Maddox \& Solórzano, 2002). Similarly, radical social workers can elicit authentic community participation in oppressed communities to address the learned helplessness and false consciousness (Quintana \& Segura-Herrera, 2003) that has led people to participate in their own oppression and dehumanization process (Windsor, Jemal, et al., 2014; Windsor, Pinto, et al., 2014). Thus, to foster liberation, radical social workers "must work collaboratively with other community members to use collective skills and resources in addressing [problems] at broader levels of the ecology, including community interventions, distribution of research information, and political involvement" (Chronister, Wettersten, \& Brown, 2004, p. 903). This is aligned with Freire's (1970, p. 66) notion that "while no one liberates himself by his own efforts alone, neither is he liberated by others." As such, a distinguishing feature of radical social work would be to conduct collaborative action with the oppressed and not for the oppressed. 
Effective anti-oppression and privilege training requires self-awareness, knowledge, and skill. Radical social work education should be geared to developing transformative potential in which students examine the nature and extent of their own social privilege, explore personal biases and beliefs and the resulting oppression, and develop their capacity for action to challenge unjust conditions (Black \& Stone, 2005). Any attempt to train culturally competent social workers without a focus on privilege is inappropriate and intentionally reinforces the oppressive status quo. The NASW code of ethics makes the integration of this content a moral imperative. Because social work is the only field with a social justiceoriented code of ethics, social workers have the specific calling not only to be a voice for those silenced, but also to provide the tools for the silenced to reclaim their voices. A social worker's good intentions do not make situations less oppressive, and saying, "I am committed to social justice," without a deep understanding that unveils oppressive realties (Freire, 1970) constitutes active collusion in maintaining the oppressive status quo (Alschuler, 1986). Social injustice, particularly oppression, is silencing, makes people unsafe and uncomfortable, denies inalienable human rights, and presents barriers to meeting hierarchical needs through one's own effort and persistence. Radical social work could help all to understand that they do not need to be card-holding members of a recognized hate group to contribute to the problem of social injustice and violence. The only way to avoid being a part of the problem is to work actively to change the culture and systems that condone oppression and privilege. Transformative potential shifts the problem from "theirs" to "ours" so that we can recognize our personal and social responsibility for combatting the disease of injustice. To know justice, we must oppose inequity. Only then can liberty and justice for all become our creed, rather than a broken promise.

\section{References}

Alexander M. The new Jim Crow: Mass incarceration in the age of colorblindness. New York, NY: The New Press; 2010.

Alschuler AS. Creating a world where it is easier to love: Counseling applications of Paulo Freire's theory. Journal of Counseling and Development. 1986; 64:492-496. DOI: 10.1002/j. 1556-6676.1986.tb01179.x

Black LL, Stone D. Expanding the definition of privilege: The concept of social privilege. Journal of Multicultural Consciousness and Development. 2005; 33:243-257. DOI: 10.1002/j. 2161-1912.2005.tb00020.x

Bronfenbrenner U. Toward an experimental ecology of human development. American Psychologist. 1977; 32:513-531. DOI: 10.1037/0003-066X.32.7.513

Carlson ED, Engebretson J, Chamberlain RM. Photovoice as a social process of critical consciousness. Qualitative Health Research. 2006; 16:836.doi: 10.1177/1049732306287525 [PubMed: 16760539]

Chronister KM, McWhirter EH. An experimental examination of two career interventions for battered women. Journal of Counseling Psychology. 2006; 53(2):151-164. DOI: 10.1037/0022-0167.53.2.151

Chronister KM, Wettersten KB, Brown C. Vocational research for the liberation of battered women. The Counseling Psychologist. 2004; 32(6):900-922. DOI: 10.1037/0022-0167.53.2.151

Corning AF, Myers DJ. Individual orientation toward engagement in social action. Political Psychology. 2002; 23(4):703-729. DOI: 10.1111/0162-895X.00304

Dunlap E, Johnson BD. The setting for the crack era: Macro forces, micro consequences (1960-1992). Journal of Psychoactive Drugs. 1992; 24:307-321. DOI: 10.1080/02791072.1992.10471656 [PubMed: 1491281] 
Dybicz P. From person-in-environment to strengths: The promise of postmodern practice. Journal of Social Work Education. 2015; 51(2):237-249. DOI: 10.1080/10437797.2015.1012923

Freire P. Pedagogy of the oppressed. New York, NY: Continuum; 1970.

Garcia M, Kosutic I, McDowell T, Anderson SA. Raising critical consciousness in family therapy supervision. Journal of Feminist Family Therapy. 2009; 21:18-38. DOI: 10.1080/08952830802683673

Ginwright S, James T. From assets to agents of change: Social justice, organizing, and youth development. New Directions for Youth Development. 2002; 96:27-46. DOI: 10.1002/yd.25

Hatcher A, De Wet J, Bonnell CP, Strange V, Phetla G, Proynk PM, ... Hargreaves JR. Promoting critical consciousness and social mobilization in HIV/AIDS programmes: Lessons and curricular tools from a South African intervention. Health Education Research. 2010; 26(3):542-555. DOI: 10.1093/her/cyq057 [PubMed: 20965911]

Hernandez P, Almeida R, Dilan Del-Vecchio K. Critical consciousness accountability, and empowerment: Key processes for helping families heal. Family Process. 2005; 44:105-119. DOI: 10.1111/j.1545-5300.2005.00045.x [PubMed: 15807081]

Jemal AD. Unpublished manuscript. Rutgers University; New Brunswick, NJ: 2016. Transformative consciousness of African American racial oppression and white racial privilege: Conceptualization, scale development and testing.

Mullaly B. Challenging oppression: A critical social work approach. Don Mills, Canada: Oxford University Press; 2002. 232

Quintana SM, Segura-Herrera TA. Developmental transformations of self and identity in the context of oppression. Self and Identity. 2003; 2:269-285. DOI: 10.1080/714050248

Sakamoto I, Pitner RO. Building critical consciousness in anti-oppressive social work practice: Disentangling power dynamics at personal and structural levels. British Journal of Social Work. 2005; 35:435-452. DOI: 10.1093/bjsw/bch190

Smith V, Jemal A. Addressing the health of formerly imprisoned persons in a distressed neighborhood through a community collaborative board. Health Promotion Practice. 2015; 16(5):733-744. DOI: 10.1177/1524839915588293 [PubMed: 26055460]

Smith-Maddox R, Solórzano DG. Using critical race theory, Paulo Freire's problem-posing method, and case study research to confront race and racism in education. Qualitative Inquiry. 2002; 8(1): 66-84. DOI: $10.1177 / 107780040200800105$

Stokols D. Establishing and maintaining healthy environments: Toward a social ecology of health promotion. American Psychologist. 1992; 47:6-22. DOI: 10.1037/0003-066X.47.1.6 [PubMed: 1539925]

Watt SK. Difficult dialogues, privilege and social justice: Uses of the Privileged Identity Exploration (PIE) Model in student affairs practice. The College Student Affairs Journal. 2007; 26(2):114-126.

Watts RJ, Griffith DM, Abdul-Adil J. Sociopolitical development as an antidote for oppression: theory and action. American Journal of Community Psychology. 1999; 27:255-271. DOI: 10.1023/A: 1022839818873

Windsor L. Using concept mapping for community-based participatory research: Paving the way for community-based health interventions for oppressed populations. Journal of Mixed Methods Research. 2013; 7(3):274-293. DOI: 10.1177/1558689813479175 [PubMed: 26561484]

Windsor L, Benoit E, Dunlap E. Dimensions of oppression in the lives of impoverished Black women who use drugs. Journal of Black Studies. 2010; 41(1):21-39. DOI: 10.1177/0021934708326875 [PubMed: 21113410]

Windsor L, Jemal A, Alessi EJ. Cognitive behavioral therapy: A meta-analysis of race and substance use outcomes. Cultural Diversity and Ethnic Minority Psychology. 2015; 21(2):300-313. DOI: 10.1037/a0037929 [PubMed: 25285527]

Windsor L, Jemal A, Benoit E. Community wise: Paving the way for empowerment in community reentry. International Journal of Law and Psychiatry. 2014; 37(5):501-511. DOI: 10.1016/j.ijlp. 2014.02.023.NIHMS576112 [PubMed: 24630737]

Windsor L, Pinto R, Benoit E, Jessell L, Jemal A. Community wise: Addressing oppression to promote individual and community health. Journal of Social Work Practice in the Addictions. 2014; 14(4): 402-420. DOI: 10.1080/1533256X.2014.962141 